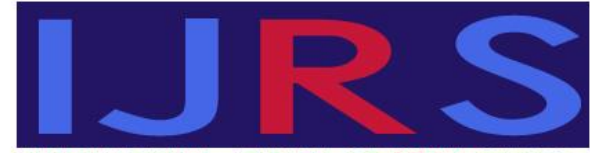

Hipatia Press

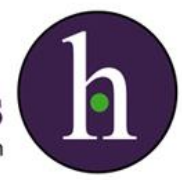

Instructions for authors, subscriptions and further details:

http://ijrs.hipatiapress.com

\title{
Colonial Privileges in a Settler Society: Disparities of Cultural Capital in a University Setting
}

David Mayeda1 ${ }^{1}$, Tepora Pukepuke ${ }^{1}$, Alan France ${ }^{1}$, Lucy Cowie ${ }^{1}$, and Marilyn Chetty ${ }^{1}$

1) The University of Auckland. New Zealand

Date of publication: March $15^{\text {th }}, 2020$

Edition period: March 2020 - September 2020

To cite this article: Mayeda, D., Pukepuke, T., France, A., Cowie, L., and Chetty, M. (2020). Colonial Privileges in a Settler Society: Disparities of Cultural Capital in a University Setting. International Journal of Roma Studies, 2(1), 4-27. doi: 10.17583/ijrs.2020.5156

To link this article: http://dx.doi.org/10.17583/ijrs.2020.5156

\section{PLEASE SCROLL DOWN FOR ARTICLE}

The terms and conditions of use are related to the Open Journal System and to Creative Commons Attribution License (CCAL). 


\section{Colonial Privileges in a Settler Society: Disparities of Cultural Capital in a University Setting}

David Mayeda

The University of Auckland

Tepora Pukepuke

The University of Auckland

Alan France

The University of Auckland
Lucy Cowie

The University of Auckland

Marilyn Chetty

The University of Auckland

\section{Abstract}

Drawing on forty one-on-one interviews with third year students from The University of Auckland, this study contrasts the experiences of students from working- and upper-class backgrounds. In particular, the study demonstrates how working-class students, most of whom come from Indigenous Māori and Pacific ethnic backgrounds, are forced to navigate obstacles infused with interpersonal and institutional racism. These students also report a stigmatising awareness of their lack of privilege and sense of obligation to give back to their ethnic communities. In contrast students from upper-class backgrounds, though hard-working, discuss a litany of opportunities extending their academic and occupational privilege. These capital-building opportunities are tightly connected to consistent family support in the form of gifted money, flexible work options, and networks that enhance professional experience. Working with kaupapa Māori and Bourdeausian conceptual frameworks, the study highlights privileged students' ability to access and extend their objectified cultural capital, as less economically privileged students work their way through colonial blockades and classed pitfalls. Given the clear disparities expressed by study participants, the research suggests universities radically reframe how resources are allocated to students from diverse backgrounds.

Keywords: Colonialism, privilege, Māori, Pacific, university, cultural capital 


\title{
Privilegios coloniales en una sociedad de colonos: Disparidades de capital cultural en un entorno universitario
}

David Mayeda

The University of Auckland

Tepora Pukepuke

The University of Auckland

Alan France

The University of Auckland
Lucy Cowie

The University of Auckland

Marilyn Chetty

The University of Auckland

\section{Resumen}

\begin{abstract}
A partir de cuarenta entrevistas individuales con estudiantes de tercer curso de la Universidad de Auckland, este estudio contrasta las experiencias de estudiantes de contextos de clase obrera y clase alta. En particular, el estudio demuestra cómo los estudiantes de clase trabajadora, la mayoría de los cuales provienen de orígenes étnicos indígenas Māorí y del Pacífico, se ven obligados a sortear obstáculos infundidos por el racismo interpersonal e institucional. Estos estudiantes también informan una conciencia estigmatizante de su falta de privilegios y su sentido de obligación de retribuir a sus comunidades étnicas. En contraste, los estudiantes de orígenes de clase alta, aunque trabajadores, discuten una letanía de oportunidades que extienden su privilegio académico y ocupacional. Estas oportunidades de creación de capital están estrechamente conectadas con el apoyo familiar constante en forma de dotación de dinero, opciones de trabajo flexibles y redes que mejoran la experiencia profesional. Trabajando con los marcos conceptuales kaupapa Māorí y Bourdiesano, el estudio destaca la capacidad de los estudiantes privilegiados para acceder y ampliar su capital cultural, mientras que los estudiantes menos privilegiados económicamente se abren camino a través de bloqueos coloniales y dificultades de clase. Dadas las claras disparidades identificadas, la investigación sugiere que las universidades deben reformular radicalmente cómo se asignan los recursos a los estudiantes de diversos orígenes.
\end{abstract}

Palabras clave: Colonialismo, privilegio, Māorí, Pacífico, universidad, capital cultural 


\section{Mayeda, et al. - Colonial Privileges in a Settler Society}

lass plays a salient role in shaping young people's lives. In particular, the amount of access young people have to different types of social capital impacts their ability to reach and succeed in institutions of higher education. Within Aotearoa New Zealand a northsouth dichotomy is traced heavily to the country's colonial history. Northern colonial influence from England has radically altered southern structures across the global south, including education systems that now serve young people from Indigenous (i.e., Māori) and diverse diasporic backgrounds. Bourdieu (1986) described capital as the resources one may acquire, whose values are contingent upon existing norms within a cultural milieu, or what Bourdieu might refer to as a field. For those young people who aspire towards tertiary studies and make it to one, the university becomes a field where students learn the "rules of the game," identifying activities and qualifications (capitals) to obtain that help secure meaningful employment following graduation (Stephens \& Gillies, 2012). However, as Bathmaker, Ingram and Waller (2013) point out, students from workingclass backgrounds find it far more difficult to game the system, or mobilise the requisite university-based capitals that will yield value in a postuniversity workplace setting. This study unpacks in-depth interviews conducted with 40 undergraduate students from The University of Auckland in Aotearoa New Zealand. More specifically, the study examines how students from different class backgrounds negotiate opportunities and challenges tied to their privilege or lack thereof. Additionally, the study makes central the role that race and Indigeneity play in the university experience, as students from Māori, Pacific, Asian and Pākehā (New Zealand European) backgrounds express how they navigate their increasingly complex university pathways.

\section{Social Privilege in Settler Societies}

Privilege is a concept denoting the advantages a group of people hold relative to others. These advantages may include increased access to material resources, greater sets of opportunities, forms of social support, higher exposure to respected social values, and/or healthier emotional and physical states. Often times, privilege includes a combination of these advantages that ebb and flow over time. Drawing on prior scholarship 
(Robinson \& Howard-Hamilton, 2000; McIntosh, 1992), Black and Stone (2005) state that social privilege includes a number of key conceptual elements, the first being that privilege signifies unearned social advantages not commonly shared by all members of society. Those afforded membership to privileged groups benefit at the expense of those not granted access to more advantaged identities (see also Rashbrooke, 2015). Moreover, those belonging to privileged backgrounds tend to lack an awareness of their advantaged status, in particular how their privilege was not earned, but bestowed upon them by others (Sanders \& Mahalingam, 2012). Those with social privilege also tend to hold higher expectations for how they will be treated (Gallo, Smith, \& Cox, 2006; Watt, 1999).

Perhaps the most important benefit those from privileged groups enjoy is that they can disengage from social disparity (Black \& Stone, 2005). Not only do privileged individuals benefit materially from social inequality, they also have the option of ignoring interpersonal and institutionalised discrimination that happens around them but does not impact them directly. In some cases, this happens consciously, but more commonly, because privileged individuals lack an awareness of their social advantages, they are oblivious to various forms of social inequality. All this enables privileged individuals to separate themselves from the discourses and layers of responsibility connected to inequity. Scholarship (Lapour \& Heppner, 2009; Harris, 1995; Reynolds \& Hope, 1991) also asserts that privilege is linked intimately to a range of social statues, such as gender, sexuality, age, and the two most germane to this study, race and class.

With respect to class privilege, that those born into high socio-economic groups frequently believe in the myth of meritocracy, which makes them feel more "comfortable with their 'earned' place in the social order" (Black \& Stone, 2005, p. 249; see also Sanders, 2012). For young people, class privilege is passed from one generation to the next when parents from privileged backgrounds provide their children with optimally resourced primary and secondary education, occupational networks, and inheritance (France, Roberts, \& Wood, 2018). Sleeter (2014) labels intergenerational privilege through inheritance as "footholds" to denote the access to opportunities, and "cushions" as the ability of such families to provide financial aid including tuition fees, as counter measures during difficult times. A number of scholars have also examined how class privilege can 


\section{Mayeda, et al. - Colonial Privileges in a Settler Society}

impact the university experience, with notable focus on a sense of belonging. Martin (2012), for example, found that "dominant class students" were more likely to be involved in campus extracurricular activities, but less likely to engage in paid work than "subordinate class students." Related scholarship has added that university students with class privilege feel a greater sense of inclusion in university communities than students from working-class backgrounds, who are more often burdened with feelings of vulnerability and a keen awareness of their lower stance in the university social hierarchy (Armstrong, Hamilton, Armstrong, \& Seeley, 2014; Stuber, Klugman, \& Daniel, 2011).

Historically, race privilege can be traced to "European imperial global expansion and colonisation, immigration, and industrialisation" (Nkomo \& Ariss, 2014, p. 390), and in contemporary settings, race privilege functions similarly to class privilege. In western contexts, race privilege typically manifests as white privilege, where those from European backgrounds are afforded the social resources that safeguard them from being harmed by race-based inequalities and attendant stressors (McIntosh, 2001; Fine, 1997). Likewise, those experiencing white privilege are often unaware of the ways they are protected from individualised racism and broader racial disparities, believing society has reached a point of colour-blindness where systemic racism was something applicable only in years past (Marable, 2002; Grillo \& Wildman, 1997). DiAngelo (2011) argues that when forced to confront their race-based privileges, white people often experience a sense of anxiety because their racialised comfort-level has been shook, a phenomena she describes as white fragility. To restore their sense of comfort, or racial equilibrium, white people may engage in a series of practices to nullify the interaction, such as exiting the conversation, asserting racism is a thing of the past, or highlighting other ways by which they have faced discrimination (e.g., classism, sexism).

Within university settings, a number of studies have explored ideas tied to white privilege and fragility. Cabrera's (2014) work with white male university students found that research participants reduced racism to individualised interactions, rendering structural racism insignificant in contemporary society, while also claiming that if racism occurred, they were victims of reverse discrimination. Other research with university students has found that white students believe their ethnic minority 
counterparts over-emphasise the importance of ethnicity (Sydell \& Nelson, 2000) and believe racism to be an overblown topic (Bunzel, 1991). Within New Zealand, Barnes, Borell and McCreanor (2014) highlight the social privilege that Pākehā (New Zealand European) experience relative to Māori: "Pākehā, as a group, continue to show higher rates of positive outcomes in education, employment, income and health. Pākehā are underrepresented in negative data across most domains, including poverty and hardship, housing, contact with the justice system, and self-reported discrimination" (p. 5; see also Borell et al., 2009).

In settler societies, racial dynamics entail a complex set of relationships between the Indigenous population and a range of settler groups. Though definitions of Indigeneity are under constant debate (Corntassel, 2003), it is generally agreed that Indigenous peoples participate in traditional cultural norms, trace their ancestry to land which prior to colonisation was politically autonomous, and continue to fight for self-determination in the present neo-colonial environment (Wilmer, 1993). Central to Indigenous peoples' political struggle and personal identities are relationships with "land, relatives, language and ceremonial life" (Alfred \& Corntassel, 2005, p. 605), which have been compromised in today's western university systems (Gaudry \& Lorenz, 2018; Lipe \& Lipe, 2017).

Colonial projects across the Pacific stem from Western European and North American imperialism (Firth, 2000). However, "Settlers are diverse, not just of white European descent, and include people of colour, even from other colonial contexts" (Tuck \& Yang, 2012, p. 7). In New Zealand's university contexts, this means accounting for patterns of privilege (A) denied to Indigenous Māori students (Theodore et al., 2015), (B) minimised for Pacific students who trace their ancestries to nearby Pacific nations (e.g., Samoa, Cook Islands, Tonga, Fiji) and whose communities were valued as un-skilled labour (Leaupepe \& Sauni, 2014; Anae et al., 2002), (C) afforded to students from more recent migrant backgrounds whose communities have been valued within the current neoliberal context but may still face racial discrimination (Simon-Kumar, 2014; Ip \& Friesen, 2001), and (D) provided to students from European middle-class backgrounds whose familial histories have not been obstructed by colonial blockades (Borell et al., 2009). In connecting these colonial and racialised histories to Bourdieu's (1986) conceptual framework, it is critical to 


\section{Mayeda, et al. - Colonial Privileges in a Settler Society}

uncover how different forms of cultural capital - institutionalised (educational qualifications), objectified (cultural goods and acquisitions) and embodied (cultural attitudes and behaviours) - are dispersed, acquired and excluded amongst students from diverse backgrounds.

\section{Methodology}

\section{Kaupapa Māori Framework}

As mentioned previously, although this study explores class as a central variable in the student experience, the research team also recognises that race and Indigeneity play fundamental roles in education systems. To this end, it is crucial that projects exploring racial disparity within Aotearoa build kaupapa Māori research principles into their frameworks (Smith, 2012). Part of taking on this research perspective entails reiterating that, "for over a century and a half the New Zealand education system has failed most of the Māori children who have passed through it" (Pihama, Cram \& Walker, 2002, p. 32). Thus, as a starting point our team recognises how racialised inequalities in New Zealand's education systems shape unequal opportunity and impact disparate experiences across the educational spectrum.

The research team engaged in a series of philosophical strategies and operational procedures to construct a project embedded with tikanga Māori (established Māori ways of doing things). These processes included consulting with Māori leadership within the university, rejecting an essentialised perception of Māori students, and ensuring we did not interpret educational failure or struggle through a deficit model that blamed Māori (Walker, Eketone \& Gibbs, 2006). The research team's demographics are also significant. Authors Tepora and Lucy are both Māori and helped perpetuate the kaupapa Māori research process by utilising te reo (the Māori language) and other elements of tikanga Māori when appropriate, including culturally upskilling the three non-Māori scholars on the research team. David is of Japanese American and European background, with training from Hawai' $i$ on Indigenous methodologies, with Alan being of British background and Marilyn of Fijian Indian descent (from Fiji, of Indian ethnicity). 
Having Māori scholars on the research team helped ensure key elements of tikanga Māori were embedded in the project's execution, as the research team met regularly to reflect on research procedures and construct the project design such that it is was by Mãori, for Māori. With that said, the project aimed to include research participants from diverse backgrounds with respect to ethnicity and class. Curtis (2016) and Naepi (2015) argue that Māori and Pacific methodologies, while not exactly the same, share considerable dimensions and point out that prior research has highlighted how Māori and Pacific students confront comparable issues in higher education (Mayeda et al., 2014a).

To incorporate the distinctive elements of kaupapa Māori methods in the research design the team discussed a range of ways to generate methods authentic to Māori. Central to the inclusion of kaupapa Māori was the intention to uphold the mana (recognised status) of Māori as tangata whenua (the first peoples of the land). Although care was taken to uphold the ongoing work of Māori researchers who have built Indigenous research capacity, the team remains vulnerable to criticism of being tokenistic. While lack of cultural knowledge and time constraints were barriers, attempts were made as a genuine effort to incorporate methods that drew on Māori principles and countered the colonial influences on research in Aotearoa New Zealand.

\section{Research Procedures and Data Analyses}

In 2018, third year students from the Faculties of Arts and Science at The University of Auckland were contacted via email and in lectures, and invited to participate in a study examining how they navigated their university experience. Third year students were selected as it was assumed they would be able to reflect critically on their university experience, identifying what has facilitated and challenged their progression through university studies. Students interested in participating were directed to an on-line survey which gathered information on their subjects of study, use of loans, and demographics (e.g., ethnicity, gender, age). This information was then used to structure a sample that was representative of domestic New Zealanders and the university student body. 


\section{Mayeda, et al. - Colonial Privileges in a Settler Society}

In all, fourty students participated in the study; 26 female, 14 male, with 23 from the Arts Faculty and 17 from Science. A fairly equal spread of participants reported Māori, Pacific, Pākehā and Asian ethnic backgrounds. With respect to ethnicity, the study deliberately over-sampled Māori and Pacific students, who are under-represented in both Faculties among third year students. Class background was determined by the high school each student attended prior to university. In New Zealand, high schools are designated a "decile" rating, which is determined by the socio-economic status of students attending each school. Research has found that students from lower-decile schools (lower socio-economic communities) are significantly under-represented in New Zealand universities (Johnston, 2018a) and that a high proportion of Māori and Pacific students attend lower-decile high schools (Johnston, 2018b; Johnston, 2015).

One-on-one kanohi ki te kanohi (face to face) interviews were conducted with participants, which lasted between 45 and 75 minutes. Authors Tepora, Lucy and Marilyn are all postgraduate students and conducted all forty interviews. Early in the research process interviewers shared their own academic experiences with one another, all recognising that their involvement in university and research life provided levels of privilege not experienced by a majority of the population. Additionally, wealth disparities within the team were acknowledged, which contributed to the methodological design through development and honing of research questions. As fellow students, the three interviewers were also able to develop a comfortable rapport with participants, allowing them to explore their educational lifestories with peers, recognise and respond to inequalities, sometimes in contrast with the scientific body of knowledge (Padrós, Garcia, de Mello \& Molina, 2011).

Participants were compensated $\$ 30$ vouchers for their time and contributions. Discussions revolved around five broad topics: (1) family background/support; (2) peer influence; (3) educational background; (4) financial circumstances; and (5) university successes and challenges. In order to maintain a comfortable rapport with participants, interviewers avoided use of the term "privilege," and instead relied upon proxies for social advantages, such as prior educational quality and family financial circumstances. 
The research team engaged in considerable dialogue to develop an interview schedule that reflected the delicate nature of interrogating participants' status, ensuring participants maintained their mana (dignity, sense of status) and did not experience whakamā (shame) if discussing private circumstances. By engaging in an ongoing dialogic relationship, the research team established a foundation that allowed for continued reflection and collaboration on the research process (Gómez, 2014). All forty interviews were transcribed in their entirety, verbatim.

As interviews transpired and throughout the transcription period, the research team met regularly to engage in thematic analyses. Respectful dialogic evaluation of the data generated a set of culturally-grounded viewpoints, such as the recurring importance of whānau (family) relationships and whanaungatanga (connection) for Māori students, highlighting the ways collectivism was needed in a university environment saturated with individualistic values. All research procedures were approved by The University of Auckland Human Participants Ethics Committee. The following sections present comparative interview data from participants who hold varying levels of class and race privilege, beginning with those exercising less social capital in their university journey.

\section{Results}

As participants from lower socio-economic backgrounds recounted their experiences of having less privilege than other students in the study, three key categories emerged. The first category was an awareness of their lack of privilege, offering examples of their home life and financial situation. Second were the "support, sacrifices and discrimination" they experienced as being less financially privileged and ethnic minorities. Third was the category of how students were engaged in a "duty of giving back."

When participants were directly asked about their family's financial circumstances they often labelled themselves, "middle class," "average," "comfortable," or "not very well off," making clear distinctions from those families of greater privilege. One male Science participant described himself as "not very well off," yet he struggled to assess the level of financial difference between his family and other families, demonstrating 


\section{Mayeda, et al. - Colonial Privileges in a Settler Society}

how lack of social mobility affects perceptions of privilege. An inability of young people to measure family wealth is mirrored by Sleeter (2014) who did not see her grandparents as wealthy even though they were able to provide a series of financial "footholds" for her family after the death of her father, resulting in Sleeter having the means to attend college and later buy a home (p. 15). This was not the kind of security less privileged participants reported in the present study.

\section{The Under-privileged Class}

Awareness of lack of privilege. Within this cohort, participants' spending behaviours were shaped by an understanding of their lesser financial circumstances, especially when they compared their spending patterns to wealthier classmates. There was an intense responsibility to acquire regular income and reduce spending. Participants took on as much part time work as they could manage alongside their studies, applied for scholarships, and accessed their Studylink entitlements (governmental loans and subsidies).

To ensure they had adequate funds for essentials (e.g., books and food) participants had to cut down on "fun purchases," such as clothes, alcohol and eating out, and regularly turning down social activities with their friends. In fact, maintaining a baseline standard of living meant most had to work part time despite this affecting their study priorities. Scholarships also supplemented income during study for a few participants, although one male Māori Arts student was told by their mother they had "no choice" but make a decision that kept them closer to home, forcing them to prioritise family connection over a full scholarship.

Support, sacrifices and racism. An exploration examined how participants were supported during study. From this arose stories of the sacrifices that families make to maintain household stability, each example demonstrating the forward thinking held by families to support participants' educational aspirations. Family support played a critical role in the provision of supplementary income and other forms of objectified cultural capital, enabling participants to have a manageable standard of living during their studies. Some students were able to reduce their expenses by 
living at home, though other participants noted their freedom was restricted due to household responsibilities and less chances to socialise. One student creatively pooled family resources to replace an aging laptop that was randomly shutting down and was not reliable, to store their assignment data:

I had a birthday recently, and basically said to all my family, if you're going to get me anything, I'll really appreciate you just giving me like $\$ 20$. Honestly, I'll put it towards the laptop - it will be mean [good]... They did; they all gave me money instead of a present, which is dumb to open on your birthday, but was also super exciting, because I knew that I could put that towards [a laptop].

Although participants from less privileged backgrounds were deeply appreciative of family support, they also recognised the sacrifices their families made to ensure that they and their siblings could enjoy a manageable standard of living and allow them to advance their institutionalised cultural capital by continuing their university studies. Many acknowledged their parents' incessant work ethic that provided the financial means for them to study. One female Pacific student stated that during an earlier life stage, her parents would go days without full meals so that she and her siblings could eat. Another participant discussed how her father's offshore work would take him away from the family for extensive time periods and declared, "For me, that sacrifice, I don't want to let it go to waste."

Unfortunately, less economically privileged students had to balance family support and sacrifice with experiences of colonialism and racism, as most participants from this cohort were Māori or Pacific. This group of participants were quick to describe encountering everyday racism on campus, as "people give me that look," prompting some Pacific students to refrain from class participation. Finally, a Māori participant described everyday colonialism (Mayeda et al., 2014b) as feeling excluded from her living space, while other students proclaimed scholarships are reserved only for Māori students, even though most university scholarships go to New Zealand's wealthiest students (Johnston, 2018c): 


\section{Mayeda, et al. - Colonial Privileges in a Settler Society}

In my first year at hall, I had a few people - I wouldn't say bullying, but making a few comments about Māori people getting scholarships. In some cases, that is kind of hard to justify; why you've got a scholarship because you're one ethnicity. So, that was kind of tough; kind of made me feel like I didn't really deserve to be there.

Duty to give back. Penehira and colleagues (2014) argue that some ethnic minorities may accept their disadvantages and lack of privilege. However, collective indigenous 'fight-back' surfaces when Indigenous peoples demonstrate resistance to their dispossession and overcome neocolonial forces. Māori and Pacific study participants showcased 'fightback' by defining university study as a means by which to gain leverage in society and break New Zealand's racialised cycles of poverty, or as RivasDrake (2008) phrases it, "moving up to give back" (p. 126). A female Tongan Arts participant clearly articulated her plan of resistance:

I'm here for one reason; to get educated, break the cycle in our community... I'm not here for you - I'm here for my people. For me, it's like I'm tired of this university and everything being run by white people, and for me, being here is important for me to get educated so that when we go out to society, we don't get treated the way that people are getting treated now. Even that's not highly emphasised or visible - the discrimination and racism [is] still happening, but for me, when I go out, I see it, because university taught us the kind of lens - the two different lenses.

Likewise, using education as a form of resistance was used by a female Māori Arts student exploring psychology as a way to reduce high Māori incarceration statistics: "So, literally - if there is a job that gets rid of that stat, then I want that job.... Yeah, so I really want to help, because it's just shocking. I want to help my people."

These participants' resolve in the face of racism though impressive, reflects additional obstacles encountered along the university pathway - a lack of educators with cultural richness and encounters with interpersonal racism - which further impede these students from accessing the objectified 
cultural capital more economically privileged students acquire with comparative ease.

\section{The Privileged Class}

Participants who attended higher decile high schools were identified initially as falling into upper-class categories. Interviews with these students generally confirmed their upper-class status. Perhaps unsurprisingly most of these participants were Pākehā or Asian (in particular Chinese). Falling in line with prior research, these students were more equipped with the material resources to game the university system and a valued set of cultural capitals which perpetuated their social advantages (Stephens \& Gillies, 2012).

Parental and family assistance. Foremost amongst this category of participants was the objectified capital they received towards tertiary studies from parents. Numerous participants in this group spoke of parents who gave them a regular allowance and/or "paid for most of my [university] fees." Financial assistance in paying for higher education meant these students had rippling advantages, one of which included not having the anxiety that typically accompanies the accumulation of debt due to taking out student loans. Participants from this more privileged class also discussed how parents bought them laptops or paid for computer technology to be fixed when necessary:

...with my laptop, I think a year ago I spilled coffee on it... It was a new one as well, so it was like, oh I need to repair it. He (participant's father) was like, yeah of course. You need this for study, so I'll just pay for it." [Chinese, female, Faculty of Arts]

In addition to covering larger expenses, more privileged participants discussed how their parents assisted with smaller, everyday costs, such as paying "for food for a week," and putting "in money for gas, and I'll say no. I don't think they should have to do that, but they do like to try to help." Provision of major and minor financial assistance helped ease student stress levels by creating an all-encompassing material and psychological safety net. 


\section{Mayeda, et al. - Colonial Privileges in a Settler Society}

Along with financial assistance, these participants were quick to discuss how their parents, and in many cases siblings, had meaningful institutionalised capital themselves in the form of university experience, which not only set an expectation for participants to attend university, but also provided knowledge on how to succeed in university. A Pākehā male participant stated, "My mum studied nursing. My dad, I'm not sure. He studied maths at one point, and I think he ended up something to do with IT. My brother studied graphic design, and my sister studied nursing."

Optional work. Nearly all study participants reported engaging in paid work at some point during their tertiary studies. However, because economically privileged students' families provided so much financial assistance, these students tended to work on top of their university studies in order to attain luxury spending money and/or gain valuable work experience. For them, work was constructed as an unnecessary but helpful option. A Pākehā female participant, for instance, stated:

I used to do a lot of waitressing. My dad owns a restaurant actually, which was pretty cool, and a lot of waitressing in my last years of high school, and a lot of work with kids as well, babysitting... this is my last year, I'm just trying to focus on uni.

Notably, paid work for this participant is facilitated by the fact that the participant's father owns a restaurant, and as this participant mentions at the end of her statement, she has since opted to stop working because she wants to "focus on uni," a luxury students from less privileged backgrounds did not enjoy. For the more privileged students, paid work stood as a bonus they could integrate into their lives as long as it did not disrupt their university studies. As another Pākehā female participant said, she elected to stop doing housekeeping work because she was offered work in her mother's company, adding, "It's such a convenient job. It's really good to have." Likewise, a male participant stated that he worked in his mother's place of employment, "which kind of works out well, because I don't really need the money...now I can be like, I've got an exam, can I just [work] the rest of the week?" In short, the personal, family connections these students had with their workplaces afforded them a privileged flexibility that augmented, but would not disturb their university studies. 
Additionally, work for this group of participants was not restricted to dead-end jobs. Rather, it was far more common amongst more privileged interviewees for paid work to be in occupational fields that built their cultural capital. While many of these participants dabbled in hospitality and care-giving work, those types of jobs were frequently dismissed when opportunities arose in law firms, tutoring companies, and other fields that would help build one's resume. And more to the point, these students also had the luxury to opt for unpaid work that bolstered their curriculum vitae.

Extra-curricular activities. The most stunning set of experiences exemplifying privilege among this group of students was their propensity to engage in forms of volunteer work that increased institutionalised capital and chances of future employment. Time and again, participants from economically privileged backgrounds discussed the different employment sectors where they worked as unpaid interns in order to "build the CV." A Pākehā female student doing her law degree alongside Arts stated, "I'm volunteering in the [a law firm] so that's quite cool. You sit in on meetings with clients and stuff. So, I'm heading to that tonight..." After being asked by the interviewer about the experience, the participant went on to say, "...it helps them (clients), but it's more for me to have an experience on my CV," indicating how conscious this participant is to build her cultural capital.

These kinds of volunteer experiences allowed participants to expand their occupational networks, learn the social cues which are valued in professional workplace settings, and acquire the kind of language needed when interacting with clients and professional mentors. However, privileged participants also discussed participating in activities that enriched their overall university experience and which broadened their personal lives. Such activities included taking international trips to visit embassies and meet with important figureheads, as well as joining in on campus clubs. As a Chinese female participant explained, although she was not majoring in business, she "wanted to diversify [her] skill-set, have a bit more knowledge." Not having the obligation to work in tedious, tiring jobs or worry about familial responsibilities provided this and similar participants from the privileged class freedom to partake in indispensable capital-building exercises. 


\section{Mayeda, et al. - Colonial Privileges in a Settler Society}

It is important to reiterate here the settler and colonial context in which these experiential differences materialise. Those students from the less economically privileged class, who were far more likely to be Māori and Pacific, were keenly aware of their lack of privilege, experienced oncampus racism, felt an obligation to give back to their ethnic communities, and noted their families' significant sacrifices. In contrast, economically privileged students, more often from Pākehā and particular Asian backgrounds, enjoyed a range of choices. If they desired luxury spending money, they could benefit from family connections to acquire paid work. If they wanted to strengthen their resume, they could obtain volunteer opportunities. And they never reported encounters with the types of racism that would question their place in the university structure.

\section{Conclusions}

While not an explict aspect of this study's findings, it is critical to highlight how elements of kaupapa Māori research contributed to this study's depth and validity. We believe that research participants from a range of ethnic and class backgrounds were comfortable enough to disclose rich details about their personal, familial and educational lives largely because interviewers established a comfortable research environment, which drew on key Māori values - manaakitanga (warmth, hospitality), whanaungatanga (connectiveness), and kia piki ake i ngā raruraru o te kainga (understanding that Māori disparities stem from colonial impositions, not Māori deficits). Articulation and demonstration of these values during interviews allowed research participants, including those who were non-Māori, to bond with interviewers and in turn, discuss issues with complexity that might otherwise be highly stigmatising. Furthermore, having Māori postgraduate students on the research team was an invaluable necessity, as these Indigenous researchers could train the other researchers in tikanga Māori (Māori customs, etiquette, and protocols) and analyse data from Indigenous lenses. While it may have been possible to conduct this study absent of kaupapa Māori research elements and without Māori researchers, such a study would have lacked adequate participant narratives, in particular reflective contributions from Māori and Pacific students. 
Returning to a Bourdeausian analysis, this study illustrates how university students from economically privileged and under-privileged backgrounds navigate their educational experience. Our study demonstrates how those students who enter university with more cultural capital perpetuate their privilege, not only because they enter the university field with so much more objectified capital (e.g., financial support from parents, slick computer technology), but also because having wide-ranging objectified capital at their fingertips gives them the freedom to extend their embodied capital. It is far easier for these students to secure internships and parlay family networks within professional fields where they are exposed to the skills, norms, and habits that will pay dividends following graduation.

In contrast, students from more working-class backgrounds spoke to the hurdles they ran into on a regular basis in their university lives. One of these hurdles was a keen awareness of the resources enjoyed by their more privileged peers, but that they lacked, leading at times to feelings of exclusion and inferiority. Unfortunately, these feelings were coupled with having to confront colonialism and racism, both interpersonally and institutionally. Therefore, while many of the Māori and Pacific students interviewed were doing well academically, they were simultaneously struggling to cope with racialised exclusion, in turn, allocating time and energy to transform experiences with discrimination into academic motivation. One might interpret these experiences with racism as forms of cultural capital, grounded in resilience and social justice. At the same time, these less privileged students are pressured to display a confident exterior that frequently masks their de facto segregation (Meuleman et al., 2014). In the meantime, they are less likely to slide into flexible paid work that builds the curriculum vitae and sets up critical occupational networks postgraduation.

Moreover, Nairn, Higgins and Ormond (2007) found that Māori and Pacific university students are further burdened with conflicting social expectations - university figureheads and peers who expect them to fail versus extended families who lean on them to succeed and become the family's economic backbone. Notably, participants from privileged backgrounds were far less likely to raise racism or other forms of discrimination as factors of any sort in their educational journey. Nor were privileged interviewees weighted with extensive familial pressure to 


\section{Mayeda, et al. - Colonial Privileges in a Settler Society}

succeed. Thus, working-class Māori and Pacific students are forced to function in an educational habitus where they learn to navigate explicit and implicit forms of racism. As third year students who are close to completing their undergraduate degrees, Māori and Pacific research participants in this study begrudgingly accumulated capital via the ongoing transformation of struggle into resilience. While these students should be commended for their ability to adapt in a structural environment riddled with classed and colonial inequalities, it is unfair to expect students from these backgrounds to take these extra measures, and one must wonder how many workingclass Māori and Pacific students drop out at earlier stages from university because they are unable to navigate racialised and classed inequalities.

Given the wide experiential disparities students face in university settings, it is imperative that university administrations (A) identify the intersectional backgrounds of students, accounting for both race and class, (B) establish robust support services for students who face race and class inequality (e.g., course support, occupational networking opportunities, personalised connections to lecturing staff) and (C) implement required programmes for staff that build an awareness of social disparity, coupled with pedagogical training that fosters a culture of inclusion for diverse student bodies. Building off this final point, universities cannot simply teach staff and students Indigenous and Pacific cultural customs. As this study has shown, ongoing colonial disparities are rooted in distinct differences of privilege, in clear power inequalities. A true offsetting of colonial privilege requires dramatic shifts in resource allocation such that Māori and Pacific families have equal access to educational and occupational capitals. Finally, university educators must construct Indigenised teaching spaces that foster cultural safety, an objective that begins with critical self-reflection on educators' colonial predispositions (Curtis et al., 2019).

\section{References}

Alfred, T., \& Corntassel, J. (2005). Being Indigenous: resurgences against contemporary colonialism. Government and Opposition, 40(4), 579614. 
Anae, M., Anderson, H., Benseman, J., \& Coxon, E. (2002). Pacific

Peoples and Tertiary Education: Issues of participation. Auckland:

The University of Auckland.

Armstrong, E. A., Hamilton, L. T., Armstrong, E. M., \& Seeley, J. L.

(2014). "Good girls": gender, social class, and slut discourse on campus. Social Psychology Quarterly, 77(2), 2014. doi:

10.1177/0190272514521220

Barnes, H. M., Borell, B., \& McCreanor, T. (2014). Theorising the structural dynamics of ethnic privilege in Aotearoa: unpacking "this breeze at my back." International Journal of Critical Indigenous Studies, 7(1), 1-14. doi: 10.5204/ijcis.v7i1.120

Bathmaker, A., Ingram, N., \& Waller, R. (2013). Higher education, social class and the mobilisation of capitals: recognising and playing the game. Journal of Sociology of Education, 34(5-6), 723-743. doi: 10.1080/01425692.2013.816041

Black, L. L., \& Stone, D. (2005). Expanding the definition of privilege: the concept of social privilege. Journal of Multicultural Counseling and Development, 33, 243-255. doi: 10.1002/j.2161-1912.2005.tb00020.x

Borell, B. A. E., Gregory, A. S., McCreanor, T., N., Jensen, H. M. B. (2009). "It's hard at the top but it's a whole lot easier than being at the bottom": the role of privilege in understanding disparities in Aotearoa/New Zealand. Race/Ethnicity: Multidisciplinary Global Contexts, 3(1), 29-50.

Bourdieu, P. (1986). Three Forms of Capital. In J. Richardson (Ed.), Handbook of Theory and Research in Education. (pp. 241-258). Westport, CT: Greenwood.

Bunzel, J. H. (1991). Black and white at Stanford. Public Interest, 105, 6177.

Cabrera, N. L. (2014). Exposing whiteness in higher education: white male college students minimizing racism, claiming victimization, and recreating white supremacy. Race, Ethnicity and Education, 17(1), 30-55. doi: 10.1080/13613324.2012.725040

Corntassel, J. (2003). Who is indigenous?: 'peoplehood' and ethnonationalist approaches to rearticulating indigenous identity. Nationalism and Ethnic Politics, 9(1), 75-100. doi: 10.1080/13537110412331301365 


\section{Mayeda, et al. - Colonial Privileges in a Settler Society}

Curtis, E. (2016). Indigenous positioning in health research: the importance of kaupapa Māori theory-informed practice. AlterNative, 12(4), 396410.

Curtis, E., Jones, R., Tipene-Leach, D., Walker, C., Loring, B., Paine, S., \& Reid, P. (2019). Why cultural safety rather than cultural competency is required to achieve health equity: a literature review and recommended definition. International Journal for Equity in Health, 18(1). doi: 10.1186/s12939-019-1082-3

DiAngelo, R. (2011). White fragility. International Journal of Critical Pedagogy, 3(3), 54-70.

Fine, M. (1997). Introduction. In M. Fine, L. Weis, C. Powell, \& L. Wong (Eds.), Off White: Readings on Race, Power, and Society (pp. viixii). New York: Routledge.

Firth, S. (2000). The Pacific Islands and the globalization agenda. The Contemporary Pacific, 12(1), 178-192.

France, A., Roberts, S., \& Wood, B. (2018). Youth, social class and privilege in the antipodes: towards a new research agenda for youth sociology. Journal of Sociology, 54(3), 362-380. doi: $10.1177 / 1440783318786580$

Gallo, L. C., Smith, T. W., \& Cox, C. M. (2006). Socioeconomic status, psychosocial processes, and perceived health: an interpersonal perspective. Annals of Behavioral Medicine, 31, 109-119. doi: 10.1207/s15324796abm3102_2

Gaudry, A., \& Lorenz, D. (2018). Indigenization as inclusion, reconciliation, and decolonization: navigating the different versions for indigenizing the Canadian academy. AlterNative: An International Journal of Indigenous Peoples, 14(3), 218-227. doi: 10.1177/1177180118785382

Grillo, T., \& Wildman, S. (1997). Obscuring the importance of race: the implications of making comparisons between racism and sexism. In Delgado, R., \& J. Stefancic (Eds.) Critical White Studies: Looking Behind the Mirror (pp. 85-102). Philadelphia: Temple University Press.

Gómez, A. (2014). How friendship generates key research questions that help to overcome gender-based violence: a personal narrative. Qualitative Inquiry, 20(7). doi: 10.1177/1077800414537220 
Harris, D. A. (1995). Multiculturalism from the Margins: Non-dominant Voices on Difference and Diversity. Westport, CT: Bergin \& Garvey. Ip, M., \& Friesen, W. (2001). The new Chinese community in New Zealand: local outcomes of transnationalism. Asian and Pacific Migration Journal, 10(2), 213-240. doi: 10.1177/011719680101000201

Johnston, K. (2018a Sept 15). Want to be a doctor, lawyer or engineer? Don't grow up poor. New Zealand Herald. https://www.nzherald.co.nz/nz/news/article.cfm?c_id=1\&objectid=1 2123299.

Johnston, K. (2018b Dec 28). The gap between the rich and poor at university in New Zealand. New Zealand Herald. https://www.nzherald.co.nz/nz/news/article.cfm?c_id=1\&objectid=1 2179117.

Johnston, K. (2018c Oct 6). Half of university scholarships go to wealthiest students while the poor struggle. https://www.nzherald.co.nz/nz/news/article.cfm?c_id=1\&objectid=1 2137326.

Johnston, K. (2015 Aug 14). World-class Auckland: education - where are we going wrong? New Zealand Herald. https://www.nzherald.co.nz/nz/news/article.cfm?c_id=1\&objectid=1 1496657.

Lapour, A. S., \& Heppner, M. J. (2009). Social class privilege and adolescent women's perceived career options. Journal of Counseling Psychology, 56(4), 477-494.

Leaupepe, M., \& Sauni, S. L. (2014). Dreams, aspirations and challenges: Pasifika early childhood education within Aotearoa New Zealand. International Journal for Cross-Disciplinary Subjects in Education, 5(3), 1711-1719.

Lipe, K., \& Lipe, D. (2017). Living the consciousness: navigating the academic pathway for our children and communities. International Journal of Qualitative Studies in Education, 30(1), 32-47. doi: 10.1080/09518398.2016.1243270

Marable, M. (2002). The Great Walls of Democracy: The Meaning of Race in American Life. New York: Basic Civitas Books. 


\section{Mayeda, et al. - Colonial Privileges in a Settler Society}

Martin, N. D. (2012). The privilege of ease: social class and campus life at highly selective, private universities. Research in Higher Education, 53(4), 426-452. doi: 10.1007/s11162-011-9234-3

Mayeda, D. T., Keil, M., Dutton, H. D., \& 'Ofamo'oni, I. F. (2014a).

"You've gotta set a precedent": Māori and Pacific voices on student success in higher education. AlterNative, 10(2), 165-179. doi: 10.1177/1177180117700799

Mayeda, D. T., 'Ofamo‘oni, I. F., Keil, M., Dutton, H. D., \& Lauaki-Vea, E. (2014b). Māori and Pacific student experiences with every-day colonialism and racism. Social Space, 8(2), 115-139.

McIntosh, P. (2001). White privilege and male privilege. In M. L. Anderson (Ed.) Race, Class, and Gender ( $4^{\text {th }}$ Edition, pp. 24-40). Belmont, CA: Wadsworth/Thomas Learning.

McIntosh, P. (1992). White and male privilege: a personal accounting of coming to see correspondences through work in women's studies. In M. L. Anderson \& P. H. Collins (Eds.), Race, Class, and Gender: An Anthology (pp. 70-81). Belmont, CA: Wadsworth.

Meuleman, A., Garrett, R., Wrench, A., \& King, S. (2014). 'Some people might say I'm thriving but...': non-traditional students' experiences of university. International Journal of Inclusive Education, 19(5), 503-517. doi: 10.1080/13603116.2014.945973

Naepi, S. (2015). Navigating the currents of kaupapa Māori and pan-Pacific research methodologies in Aotearoa New Zealand. MAI Journal, 4(1), 70-84.

Nairn, K., Higgins, J., \& Ormond, A. (2007). Post-school horizons: New Zealand's neo-liberal generation in transition. International Studies in Higher Education, 17(4), 349-366. doi:

10.1080/09620210701667004

Nmoko, S. M., \& Ariss, A. A. (2014). The historical origins of ethnic (white) privilege in US organizations. Journal of Managerial Psychology, 29(4), 389-404.

Padros, M., Garcia, R., De Mello, R., \& Molina, S. (2011). Contrasting scientific knowledge with knowledge from the lifeworld: The dialogic inclusion contract. doi: 10.1177/1077800410397809

Penehira, M., Green, A., Smith, L.T, \& Aspin, C. (2014). Māori and Indigenous views of $\mathrm{r} \& \mathrm{r}$. Resistance and resilience. MAI Journal. 
http://www.journal.mai.ac.nz/sites/default/files/MAI_Jrnl_V3_iss2_P enehira.pdf.

Pihama, L., Cram, F., \& Walker, S. (2002). Creating methodological space: a literature review of kaupapa Māori research. Canadian Journal of Native Education, 26(1), 30-43.

Rashbrooke, M. (2015). Wealth and New Zealand. Wellington: Bridget Williams Books.

Reynolds, A. L., \& Pope, R. L. (1991). The complexities of diversity: exploring multiple oppressions. Journal of Counseling \& Development, 77, 73-79. doi: 10.1002/j.1556-6676.1991.tb01580.x

Rivas-Drake, D. (2008). Perceived opportunity, ethnic identity, and achievement motivation among Latinos at a selective public university. Journal of Latinos and Education, 7(2), 113-128. doi: 10.1080/15348430701828632

Robinson, T. L., \& Howard-Hamilton, M. F. (2000). The Convergence of Race, Ethnicity and Gender: Multiple Identities in Counseling. Upper Saddle River, NJ: Merrill.

Sanders, M. R., \& Mahalingam, R. (2012). Under the radar: the role of invisible discourse in understanding class-based privilege. Journal of Social Issues, 68(1), 112-127. doi: 10.1111/j.15404560.2011.01739.x

Si'ilata, R., Samu, T. W., \& Siteine, A. (2017). The Va 'atele Framework: Redefining and Transforming Pasifika Education. Handbook of Indigenous Education, 1-30.

Simon-Kumar, R. (2014). Neoliberalism and the new race politics of migration policy: changing profiles of the desirable migrant in New Zealand. Journal of Ethnic and Migration Studies, 41(7), 1172-1191. doi: 10.1080/1369183X.2014.936838

Sleeter, C. (2014). Inheriting footholds and cushions: family legacies and institutional racism. Counterpoints, 449, 11-26.

Smith, L. (2011). Experiential 'hot' knowledge and its influence on lowSES students' capacities to aspire to higher education. Critical Studies in Education, 52(2), 165-177. doi:

10.1080/17508487.2011.572829

Smith, L. T. (2012). Decolonizing Methodologies: Research and Indigenous Peoples: Second Edition. New York: Zed Books. 
26 Mayeda, et al. - Colonial Privileges in a Settler Society

Stephens, C., \& Gillies, A. (2012). Understanding the role of everyday practices of privilege in the perpetuation of inequalities. Journal of Community \& Applied Social Psychology, 22, 145-158. doi:

$10.1002 /$ casp. 1107

Stuber, J. M., Klugman, J., \& Daniel, C. (2011). Gender, social class, and exclusion: collegiate peer cultures and social reproduction.

Sociological Perspectives, 54(3), 431-451. doi:

10.1525/sop.2011.54.3.431

Sydell, E. J., \& Nelson, E. S. (2000). Modern racism on campus: a survey of attitudes and perceptions. Social Science Journal, 37(4), 627-636. doi: 10.1016/S0362-3319(00)00105-1

Theodore, R., Tustin, K., Kiro, C., Gollop, M., Taumoepeau, M., Taylor, N., Chee, K., Hunter, J., \& Poulton, R. (2015). Māori university graduates: indigenous participation in higher education. Higher Education Research \& Development, 35(3), 604-618. doi: 10.1080/07294360.2015.1107883

Tuck, E., \& Yang, K. W. (2012). Decolonization is not metaphor.

Decolonization: Indigeneity, Education \& Society, 1(1), 1-40.

Walker, S., Eketone, A., \& Gibbs, A. (2006). An exploration of kaupapa

Māori research, its principles, processes and application.

International Journal of Social Research Methodology, 9(4), 331344. doi: 10.1080/13645570600916049

Watson, S., Vernon, L., Seddon, S., Andrews, Y., \& Wang, A. (2016). Parents influencing secondary students' university aspirations: a multilevel approach using school-SES. Issues in Educational Research, 26(4), 673-693.

Watt, S. K. (1999). The story between the lines: a thematic discussion of the experience of racism. Journal of Counseling \& Development, 77, 54-61. doi: 10.1002/j.1556-6676.1999.tb02420.x

Wilmer, F. (1993). The Indigenous Voice in World Politics. Newbury Park, CA: Sage. 
David Mayeda is Senior Lecturer at The University of Auckland in sociology and criminology.

Tepora Pukepuke is a Māori doctoral student at the University of Auckland.

Alan France is Professor of Sociology at the University of Auckland.

Lucy Cowie (Ngāti Ranginui) is completing a Doctorate of Clinical Psychology at the University of Auckland.

Marilyn Chetty is a doctoral candidate in Criminology at the University of Auckland.

Contact address: d.mayeda@auckland.ac.nz 